Russian Academy of Sciences, Far Eastern Branch

Botanical Garden-Institute

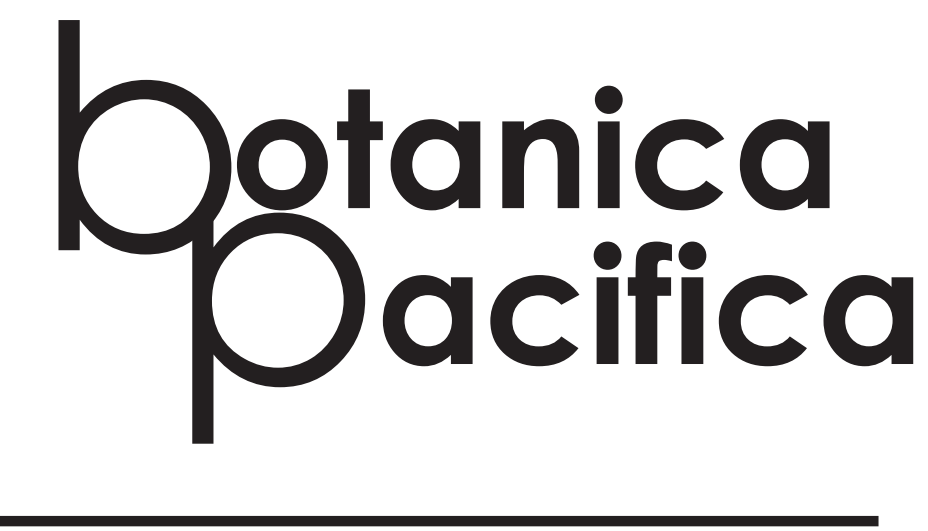

A JOURNAL OF PLANT SCIENCE
AND CONSERVATION

VOLUME 9, NO. 12020 


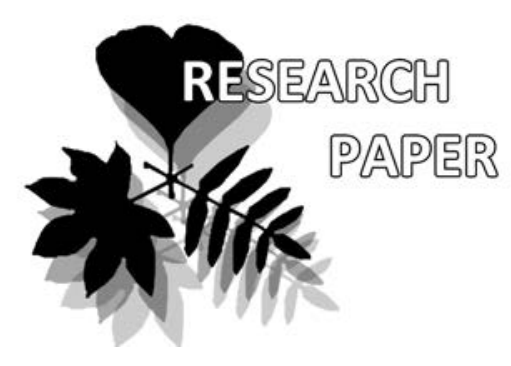

\title{
Ontomorphogenesis and the state of endemic Dracocephalum charkeviczii Probat. (Lamiaceae) coenopopulations in Primorsky Territory (Russia)
}

\author{
Gulnora R. Denisova* \& Alexey Yu. Astashenkov
}

Gulnora R. Denisova*

e-mail: gulnoria@mail.ru

Alexey Yu. Astashenkov

e-mail:astal@bk.ru

Central Siberian Botanical Garden SB

RAS, Novosibirsk, Russia

* corresponding author

Manuscript received: 29.04.2018

Review completed: 25.12.2019

Accepted for publication: 16.02.2020

Published online: 25.02.2020

\begin{abstract}
A B S T R A C T
We studied ontomorphogenesis of sympodially accreting short-rhizome perennial species Dracocephalum charkeviczii Probat. and the ontogenetic structure of its coenopopulations. The ontogenesis is consedered for a maternal individual and particles. The course of development of $D$. charkeviczii individuals may be expressed by the following morphogenetic phases: primary shoot $\rightarrow$ primaty bush $\rightarrow$ loose bush $\rightarrow$ tillering particle $\rightarrow$ not tillering particle. We found dynamic and dimensional polyvariation in the species. The differences in the development between the $D$. charkeviczii and closely related species $D$. argunense and $D$. ruyschiana from the subgenus Ruyschiana were shown. We identified two types of real spectra: righthand and centered. The ontogenetic structure of coenopopulations is determined by species biology and growth conditions (availability of free substrate, degree of coenosis turfness and soil moisture).
\end{abstract}

K e y w o r d s : Dracocephalum charkeviczii, ontogenesis, ontogenetic structure, coenopopulation, Primorsky Region, the Russian Far East

\section{P E 3 Ю M E}

Аенисова Г.Р., Асташенков А.Ю. Онтоморфогенез и состояние ценопопуляций энАемичного виАа Dracocephalum charkeviczii Probat. (Lamiaceae) в Приморском крае. Изучены онтоморфогенез симподиально нарастающего короткокорневищного многолетника Dracocephalum charkeviczii Probat. и онтогенетическая структура его ценопопуляций. Онтогенез сложный, состоит из онтогенеза материнской особи и партикул. Путь развития особей $D$. charkeviczii вкАючает следующие фазы морфогенеза: первичный побег $\rightarrow$ первичный куст $\rightarrow$ рыхлый куст $\rightarrow$ кустящаяся партикула $\rightarrow$ некустящаяся партикула. У вида установлена Аинамическая и размерная поливариантность. Показаны различия в развитии D. charkeviczii с близкородственными видами D. argunense и D. ruyschiana из подрода Ruyschiana. Вылелены два типа реальных спектров ценопопуляций: правосторонний и центрированный. Онтогенетическая структура ценопопуляций определяется биологией вида и условиями произрастания (наличием свободного субстрата, степенью заАернованности ценоза и влажностью почвы).

КАючевые слова: Dracocephalum charkeviczii, онтогенез, онтогенетическая структура, ценопопуляция, Приморский край, Аальний Восток
Study of populations is currently essential for making decision in plant conservation, as well as in rational use and reestablishing communities (Rabotnov 1975, Smirnova \& Toropova 2004, Rockwood 2006, Zlobin et al. 2013). Precise knowledge of species biology and coenopopulation structure is important for understanding the potential for development of population in ecological conditions of a particular habitat (Harper 1977, Zhukova 1995, Cheryomushkina 2004, Antonova et al. 2008, Tabuldin 2009, Chistyakova 2011). In this study we focus on Dracocephalum charkeviczii Probat., an endemic species, belonging to the subgenus Ruyschiana.

Dracocephalum charkeviczii individuals have relatively large (up to $4-5 \mathrm{~cm}$ ) flowers with blue-purple corollas. In the wild we noted individuals with white and rose petals.

This paper focuses on study of the course of ontogenesis and ontogenetic structure of $D$. charkeviczii coenopo- pulations and comparison of its development with that of closely related species.

\section{MATERIAL AND METHODS}

Dracocephalum charkeviczii, a coastal race of $D$. argunense Fisch. ex Link was described by Probatova (1995) as a separate species. Its individuals form a short-rhizome life form. The shoot system of this species is formed by alternating in time monocarpic monocyclic elongated orthotropic and anisotropic shoots.

According to Kozhevnikov et al. (2015) D. charkeviczii is a endemic species for Sikhote-Alin and Southern Kuril regions. In Russia, individuals of this species grow only in the south of the Russian Far East. They are protected in Sikhote-Alin, Lazo and Far Eastern Marine Nature Reserves. According to Pimenova (2016), this species occurs near the northern limit of its range in the territory of Sikhote-Alin 
Nature Reserve. The Korean Peninsula accommodates the southern populations of $D$. charkevicaii. Distribution of the species is linked with the coastal line, species never occurs in depth of mainland.

Dracocephalum charkeviczii is a meadow species (Kozhevnikov et al. 2015) occurring in maritime meadows, on the slopes of sea terraces, seaside sands and pebbles (Probatova 1995). According to our observations, D. charkeviczii creates aspect as it blooms and often appears to be codominant in meadows rich in herbs on the sea terraces.

We studied ontogenesis and ontogenetic structure of D. charkeviczii coenopopulations in the territory of Primorsky Region of the Russian Far East. The coenopopulations studied were isolated from each other and grew on sea terraces near the coast. We examined coenopopulations in Pogranichnaya Bay of Popov Island (coenopopulation 1) and in Karpinsky Bay of Russkiy Island (coenopopulation 2). Coenopopulation 1 was recorded in grass-dragonhead meadow (42 $566^{\prime} 27.9^{\prime \prime} \mathrm{N} 131^{\circ} 43^{\prime} 38.6^{\prime \prime E}, 716 \mathrm{~m}$ a.s.l.) dominated by D. charkeviczii - $25 \%$ (cover), Koeleria tokiensis Domin $20 \%$ and Bromopsis inermis (Leysser) Holub - $20 \%$. Accompanying species were Galium vaillantii - 3\%, Calamagrostis langsdorffii (Link) Trin. - $3 \%$, Plantago camtschatica Link $2 \%$, Stellaria filicaulis Makino - 2\%; Iris ensata Thunb. - 1\%, Ptarmica ptarmicoides (Maxim.) Worosch. $-1 \%$ and others. The total cover reached $90-95 \%$. The maximum height of herb layer was $80-100 \mathrm{~cm}$. We examined Coenopopulation 2 in meadow, rich in herbs $\left(42^{\circ} 57^{\prime} 56.4^{\prime \prime} \mathrm{N} 131^{\circ} 52^{\prime} 58.7^{\prime \prime} \mathrm{E}\right.$, $713 \mathrm{~m}$ a.s.l.) dominated by Geranium sieboldii Maxim. - $25 \%$, Artemisia mandshurica (Kom.) Kom. - $20 \%$, Astragalus marinus Boriss. - $15 \%$, D. charkeviczii-10\%. Lower cover was characteristic of Trifolium pacificum Bobr. - 2\%, Festuca rubra L. $-2 \%$, Plantago camtschatica - 1\%, Oxytropis ruthenica Vass. $-1 \%$, Galium vaillantii $\mathrm{DC}-1 \%$ and others. The total cover reached $85-90 \%$. The maximum height of herb layer was $50-70 \mathrm{~cm}$.

The life forms of mature individuals of D. charkeviczii were identified according the ecological-morphological concept of Warming-Serebryakov (Warming 1884, Serebryakov 1962).

The ontogenesis of plants was described in accordance with the concept of discrete ontogenesis (Rabotnov 1950, Uranov 1975, Serebryakova \& Sokolova 1988) based on identification of the stages characterizing qualitative indicator features of the process of individual development. Plant traits were studied by methods of Serebryakova (1971), Smirnova \& Uranov (1976) and Savinykh \& Cheryomushkina (2015) We assessed the biometric characteristics of 20 adult individuals, calculated mean values and errors (Table 1) for each trait and applied the Student t-test for finding if the means between individuals are different. All calculations were performed in Excel.

We determined 5 phases of morphogenesis in the ontogenesis of D. charkeviczii: (1) primary shoot - a leading shoot developing from a seed and having a rootlet and secondary roots; (2) primary bush formed as a result of branching of a leading shoot in its basal part; (3) a loose bush formed as a result of manifold branching of a leading shoot in its basal part, the root-system is mixed; (4) tillering particle (a secondary bush) formed as a result of division of rhizome, which keeps branching, tillering particles are spatially separated; (5) not-tillering particle - a shoot that lost ability to branch.

When studying the ontogenetic structure of coenopopulations, we used the procedures of Gatsuk et al. (1980). The ontogenetic structure of coenopopulations was defined as the ratio of individuals of different ontogenetic states in the coenopopulation. We measured the ontogenetic structure on random plots 1 by $1 \mathrm{~m}$ in size. The traits were measured on an individual plant if it was under old generative stage, and on a particle, if plant was in old generative and postgenerative periods.

For detailed characteristics of coenopopulations we used the following demographic indices: ecological density (Odum 1975), recovery index (Zhukova 1987) and senescence index (Glotov 1998). To assess the status of coenopopulations we applied "delta-omega" classification of Zhivotovskii (2001).

\section{RES U LTS}

D. charkeviczii seeds are dark brown, elongate-oval, triangular, 2-3 $\mathrm{mm}$ long, $1.5 \mathrm{~mm}$ wide. Germination is aboveground as in all Dracocephalum species.

Seedlings appear in spring or in late summer and are characterized by formation of one top-rosetted shoot with two wedge-shaped cotyledons and two pairs of petiolar, opposite, simple lanceolate, entire leaves. Bud initiation is in the nodes of cotyledonary and the first pair of true leaves. The hypocotyl is short, only $2 \mathrm{~mm}$. Due to elongation of the epicotyl up to 7-9 $\mathrm{mm}$, the height of shoot reaches $11-$ $13 \mathrm{~mm}$. The main root is twice longer than a primary shoot $(25-27 \mathrm{~mm})$. The system of lateral roots is well-developed, their branching in a seedling reaches the third order.

Depending on the site of seed germination, polyvariation of individual development in the juvenile stage which comes in the same year is revealed (Fig. 1).

All individuals keep accreting monopodially. Most of juvenile individuals have an elongated primary shoot. All internodes elongate: epicotyl length-up to 28-32 mm, hypocotyl sizes-up to $10-12 \mathrm{~mm}$. 3-4 pairs of true leaves develop on the shoot $5.9-6.4 \mathrm{~cm}$ high. The shape of leaves remains unchanged with plant growing. Blade length is $12-14 \mathrm{~mm}$, width is $3-4 \mathrm{~mm}$. Sizes of the main root do not change. An initial shoot of the plants growing on heavily turfed sites remains top-rosetted. The length of epicotyl reaches $18-20 \mathrm{~mm}$ and remains unchanged during the plant lifespan. The same number of metamers are developed on the overgrid shoot as on the elongated shoot. In the root system, 1-2 lateral roots of order I are developed similarly to the main one. The length of the main root increases up to $35-42 \mathrm{~mm}$. Due to contractile root activity the hypocotyl and a part of the epicotyl of the shoot in all individuals are deepen in soil. In autumn the shoot dies off up to the node with cotyledonous leaves, the hypocotyl and the node with cotyledonous leaves become the first link of the rhizome.

In the second year, plants go into the immature ontogenetic stage which is characterized by change of accretion of the shoot system for sympodial one. More often, two buds 


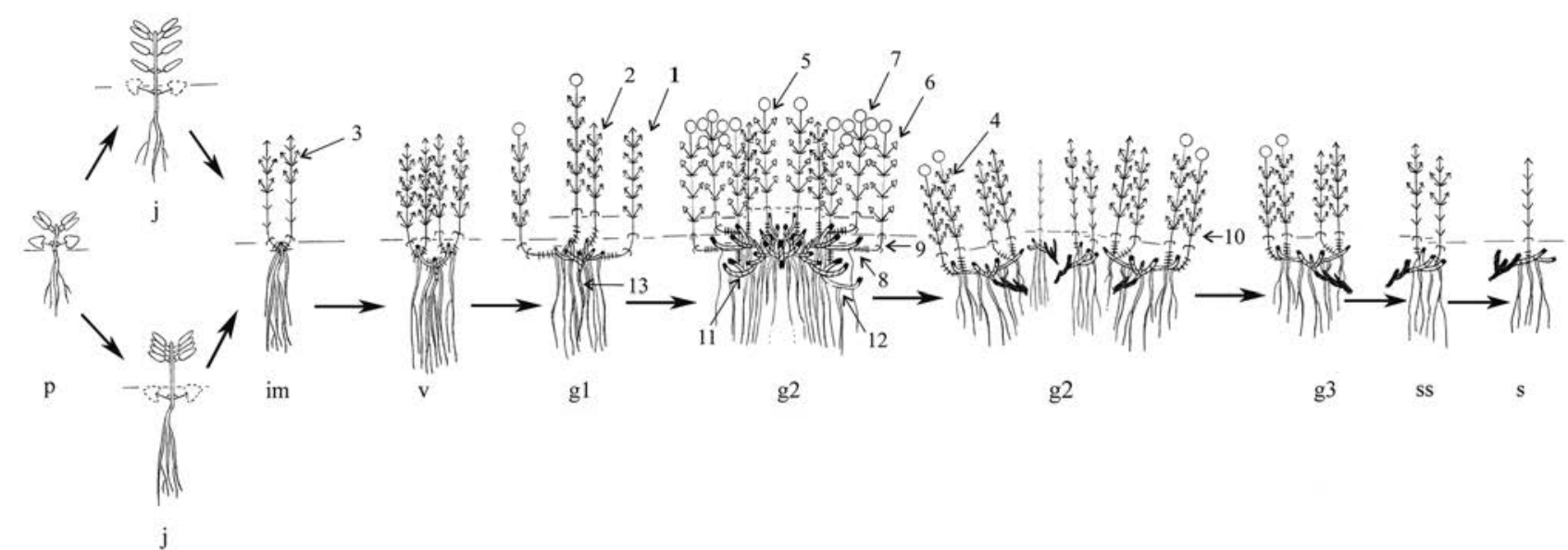

Figure 1 The ontomorphogenesis of Dracocephalum charkeviczii Probat. individuals. Ontogenetic states: $p-$ plantlet, $j$ - juvenile of first year of life, $j 2$ - juvenile of the second year of life, im - immature, $v$ - virginal, $g 1$ - young generative, $g 2$ - mature generative, g3 - old generative, ss - subsenile, s - senile; _ _ ground level; _ - the way of development of individuals; 1 - vegetative anisotropic elongated branching shoot; 2 - vegetative orthotropic elongated branching shoot; 3 - vegetative rosetted enrichment shoot; 4 - vegetative elongated enrichment shoot; 5 - monocarpic elongated shoot; 6 - monocarpic anisotropic shoot; 7 - synflorescence, 8 - shortened metamer with a scaly leaves; 9 - elongated metamer with transient leaves; 10 - elongated metamer with true leaves; 11 - hypogeogenic rhizome; 12 adventitious root; 13 - main root

from the cotyledonous leaf axil start to grow, and plants pass into the following phase of morphogenesis - primary bush. In some individuals only one bud starts growing, another bud becomes dormant. Ortotropic elongated regenerative shoots of order II consist of one shortened metamer with scale-shaped leaves and 6-8 elongated metamers with one pair of transient and 5-7 pairs of true lanceolate leaves. Lateral bud initiation is in all leaf axils. Shoot height is up to 8 $\mathrm{cm}$. At this stage the shoots branch out in the above-ground part. Lateral rosetted enrichment shoots develop from the buds in axils of the third and forth pairs of green leaves. After the vegetative shoots die off up to the basal part at the level of the metamer with transient leaves which becomes the following link of the rhizome. Root system is mixed, presented by well-developed main, lateral and one or two secondary roots. The main root is about $5 \mathrm{~cm}$ long and branches out up to order IV. Adventitious roots develop in the nodes of cotyledonous leaves. Due to contractile root activity basal parts of shoots are constantly drawn in soil. The immature stage lasts one year.

In the third year plants pass into the virginal stage. A primary bush consists of 2-4 ortotropic elongated shoots of the immature type. Buds in transient leaf axils start in growth, the rest of buds become dormant. Such annual development of shoots leads to formation of the sympodial rhizome, a basal part of the shoot with scale-shaped and transient leaves enters into its composition annually. Unlike the previous stage, shoots in the above-ground part branch out along their full length. All buds in green leaf axils, except for two bud pairs in the apical shoot part, unfold. Lateral rosetted shoots are formed from the lower and upper bud pairs started in growth, from the rest of buds top-rosetted enrichment shoots. True leaves are oblong-elliptic, $2.3-2.6 \mathrm{~cm}$ long, $0.3 \mathrm{~cm}$ wide. In the under-ground sphere it is difficult to identify the main root among welldeveloped lateral and adventitious roots. Adventitious roots develop in the nodes of the first metamers of the shoot of the current growth and reach sizes of the main root over one vegetative season. The main, lateral and adventitious roots branch out. Duration of the stage is 1-2 years.

In the forth or fifth year individuals begin to bloom. A primary bush of young generative plants consists of 2-4 vegetative and 1-2 generative regeneration shoots, 23.1$26.8 \mathrm{~cm}$ and $29.8-33.0 \mathrm{~cm}$, respectively. For the most part regeneration shoots are ortotropic, but in young generative stage develop a small number of anisotropic shoots. Their plagiotropic part consists of 3-4 shortened metamers with scale-shaped leaves and may reach $2 \mathrm{~cm}$ in length. On the soil surface, from the apical bud unfolds an ortotropic shoot part consisting of 7-11 elongated metamers, 1-2 of which are with transient and 6-10 with true green leaves. Metamers with transient leaves are in the apogeotropic shoot part. One or two anisotropic shoots are generative. In the structure of ortotropic shoots, the number of shortened metamers with scale-shaped leaves increases up to 4, and the number of metamers with transient and true leaves remains as at previous stage. A geophilous part of all shoot types becomes the following link of the rhizome. Shoot height changes due to elongation of internodes up to 2.5 $\mathrm{cm}$. Regeneration buds in all shoot types are initiated in axils of two upper scale-shaped and transient leaves. The rest of buds in the axils of scale-shaped leaves become dormant. Regeneration shoots of the above-ground part branch out: rosetted shoots unfold on the vegetative shoots, toprosetted shoots-on the monocarpic ones. The inflorescence is a frondose open spikelike thyrse. In young generative plants it reaches $1-1.2 \mathrm{~cm}$ in length and consists of two pairs of opposite dichasia. It is difficult to identify the main root among adventitious roots. It dies off at the end of the young generative stage. The stage lasts one to two years.

D. charkeviczii individuals in the mature generative stage are in the phase of a loose bush. Eight to fifteen generative and 3-5 vegetative shoots form the basis for the shoot system of a bush, $30 \%$ of generative shoots are anisotropic, the other are orthotropic. Shoot height does not grossly change, generative shoots may reach $33.1-37.3 \mathrm{~cm}$ and ve- 
getative ones - 27.2-29.8 cm. Shoot height increases due to elongation of metamers up to $3.8 \mathrm{~cm}$, their number is kept the same. Shoot structure is typical of young generative individuals. The number of metamers increases up to 5-6 in the plagiotropic part in only anisotropic shoots. Their geophilous part reaches $3 \mathrm{~cm}$ and fits into the general rhizome structure. Some shoots lodge partially in the course of their development. In such a case in the first 1-2 nodes with true leaves develop adventitious roots and initiate buds. The plagiotropic part of such shoots may reach $6 \mathrm{~cm}$. Vegetative elongated shoots develop from the buds next year, at the end of the vegetative season they die off completely. All shoots continue to branch out. At this stage elongated vegetative enrichment shoots develop on generative shoots, rosetted and top-rosetted shoots develop on vegetative shoots. Shoot formation is carried out due to both realization of regeneration buds and opening of dormant buds. The loose bush spreads out for the great number of shoots and may reach $12 \mathrm{~cm}$ in diameter. The inflorescence length increases up to $6.4 \mathrm{~cm}$, the number of whorls is up to 6 . Very seldom D. charkeviczii individuals develop 2-4 paracladia that form synflorescence, which represents a cluster in which an open frondose thyrse is a floral unit. Synflorescence is formed most often at damage of the terminal bud of generative shoots. Adventitious root system is well developed in the underground sphere. Length of adventitious roots may reach $35 \mathrm{~cm}$. The mature generative stage lasts up to 4 years.

At the late mature generative stage, the basal part of the main shoot system dies off completely. As a result of individual disintegration a clone is formed and plants pass into the following morphogenetic phase - "tillering particle". Separated particles of the clone are in the old generative subsenile or senile stages. Uneven-aged particles in the underground sphere are interlaced with the great number of adventitious roots. As a result particulation does not lead to an individual sprawl.

Particles of the old generative stage have 1-2 generative and 1-3 vegetative orthotropic shoots, $25-30.2 \mathrm{~cm}$ and $18.5-20.4 \mathrm{~cm}$ high, respectively. Shoots develop from regeneration buds in the nodes with transient or the last pair of scale-shaped leaves. They branch out in the aboveground part. Anisotropic shoots do not develop. A rhizome is perennial, spreads out due to shoot basal parts. Its functionally active part represents a sympodial axis consisting of two, seldom three annual increments. Rhizome dying off takes place from the proximal end due to destruction of old parts.

Subsenile individuals have a small remaining living part of rhizome that consists of 1-2 annual increments. In this stage, the location of the renewal zone on the shoot changes. Shoots are formed by means of regeneration buds unfolding in the penultimate or ultimate nodes with scaleshaped leaves on the basal part of last year shoot. Emerged vegetative shoots in numbers $1-2$ are of the immature type, their height does not exceed $12.3-18.5 \mathrm{~cm}$.

Not tillering particles of individuals at the senile stage are presented by a solitary shoot of the juvenile type. A shoot is formed owing to development of a dormant bud on the preserved rhizome part and consists of a shortened metamer with scale-shaped and elongated metamers with transient and true leaves. Height of a regeneration shoot may reach $16 \mathrm{~cm}$. A small number of adventitious roots develop in the underground part of a particle.

Dynamic and dimensional polyvariation is characteristic of $D$. charkeviczii individuals in different plant communities (Table 1).

Dynamic polyvariance is expressed when individuals enter the phase of the loose bush in a mature generative state. The duration of this phase in individuals growing in a herb-rich meadow (coenopopulation 2) is 5-6 years. Individuals growing in the grass-dragonhead meadow develop in the phase of a loose bush for 4 years.

Comparison of means of biometric indices of plants at the mature generative stage between two coenopopulations shows that coenopopulations significantly different in all characters except the number of whorls, vegetative and generative shoots (Table 2). The individuals growing in grassdragonhead meadow (coenopopulation 1) are much higher than those growing in the species rich meadow (coenopopulation 2). This is explained by shading of $D$. charkevicaii individuals in coenopopulation 1 by high grass.

\section{DISCUSSION}

A comparative analysis of $D$. charkeviczii individuals and closely related species from the subgenus Ruyschiana (Mill.) Benth., genus Dracocephalum L., shows that the life forms and ontogenesis patterns of all representatives in taxonomic group is similar.

The subgenus Ruyschiana comprises four species: D. ruyschiana L., D. argunense Fisch. ex Link., D. austriacum L. and D. charkeviczii, all growing in Eurasia. In all species, plants are perennial, sympodially accreting, short-rooted, with elongated monocyclic shoots.

D. ruyschiana is the most widelly distributed species in the subgenus. It occurs in Central Europe, West and East Siberia with the only location in the Tu River Basin in the Russian Far East (Probatova 1995). Outside Russia, it was recorded in northern China, north-east Mongolia, Inner Mongolia and southern Kazakhstan (Shishkin 1954). The species is closely related with the steppe and foreststeppe areas. It occurs in forest margins, shrubs on slopes, sometimes on pebbles, at altitudes up to $2000 \mathrm{~m}$ a.s.l.

D. austriacum occurs in steppes and meadow, sometimeson limestone outcrops and stony slopes, in subalpine meadows up to $2400 \mathrm{~m}$ a.s.l. in Western and Central Europe, the Caucasus and Turkey (Budantsev 1993).

D. argunense grows in meadows, species rich steppes, in forest margins and shrub, on pebbles, diverse stony and dry slopes below 1000 m a.s.l. in the Russian Far East, northeast China, eastern Mongolia, Korea and Japan. The distribution range of $D$. argunense in the Russian Far East overlaps with that of D. charkeviczii, the habitats of the latter located on the sea coast.

Our analysis of ontogeneses of D. ruyschiana and D. argunense individuals (Denisova \& Kovalyova 2007, Denisova et al. 2018) and ongotenesis of D. charkeviczii showed that sympodial accrement of shoot systems in is all three 
species is realized through the formation of annual monocyclic monocarpic shoots from regeneration and dormant buds. As a result, a perennial part of individuals is presented by a sympodium of $\mathrm{n}$-order branching. In such plants buds in the regeneration zone are realized successively in the course of several years. In $D$. argunense and $D$. ruyschiana individuals, buds of the second and third metamers with scale-shaped leaves are the first to start growth, in D. charkeviczii individuals, shoot development starts from the buds of the last metamers (4-6) with scaleshaped and transient leaves.

Regeneration shoots branch out in all three species. On the axis of generative shoots of $D$. argunense and D. ruyschiana adult individuals unfold enrichment shoots of orders I и II. On monocarpic branched shoots of $D$. charkeviczii only enrichment shoots of order I are distinguished.

The general nature of the development of individuals of all three species fits into one type of ontogenesis, which consists of the ontogeneses of the mother individual and partial formations. Daughter individuals do not rejuvenate. The main way of development of $D$. argunense and D. ruyschiana individuals may be expressed by a sequence of the following morphogenesis phases: primary shoot $\rightarrow$ main axis $\rightarrow$ primaty bush $\rightarrow$ loose bush $\rightarrow$ tillering particle $\rightarrow$ not tillering particle. The development of $D$. charkeviczii individuals passes through the phases: primary shoot $\rightarrow$ primaty bush $\rightarrow$ loose bush $\rightarrow$ tillering particle $\rightarrow$ not tillering particle. The main distinction of these closely related species in the course of morphogenesis: the phase "ain axis" is absent in D. charkeviczii ontogenesis. The most continuous morphogenesis phase in all species is the loose bush phase.

The analysis of the ontogenetic structure of D. charkevi$c z i i$ coenopopulations shows that in connection with dominance of different ontogenetic groups in the spectra, the real spectra are divided into two types: right-hand in coenopopulation 1 and centered in coenopopulation 2 (Table 2).

Almost half of individuals from coenopopulation 1 are in the old generative stage $(44.94 \%)$ than can be explained by continuing process of individual particulation in late mature generative stage with formation of senescent daughter particles. Low indices of the pregenerative individuals $(7.85 \%)$ are likely connected with poor seed germination due to lack of free substrate and elimination of young growth due to strong turfness in the plant community made by Koeleria tokiensis and Bromopsis inermis. Despite a small percentage of individuals of the pregenerative period, a smooth rise in the values occurs on the left side of the spectrum, which nevertheless indicates a rather successful transition of individuals from one ontogenetic state to another. A small proportion of pregenerative individuals in coenopopulation 1 is reflected in low value of the index of recovery $(\mathrm{Ir}=0.09)$ and means too poor regeneration in the coenopopulation. Because of constant replenishment of the coenopopulation by old generative and postgenerative individuals $(\mathrm{g} 3+\mathrm{ss}+\mathrm{s}=65.18 \%)$, the coenopopulation has a high value of the index of senescence (Is=0.67), and on basis of age assessment $(\Delta-$ delta) and efficiency ( $\omega$-omega) is senescent. Most likely such a structure of the coenopopulation is linked with recent appearance of grasses in the community which gradually displace $D$. charkeviczii individuals.

The coenopopulation 2 has a centered type of spectrum, in which a gradual accumulation of immature to mature generative individuals cause a smooth decline of the postgenerative plants. Such type of spectrum is due to annual replenishment of the coenopopulation with individuals of seed origin and their transition to the mature generative stage, which lasts 5-6 years longer in individuals growing in not turfed community. Coenopopulation 2 is formed in the plant community, in which despite a high cover (85-90\%) of grasses, D. charkeviczii has favourable conditions for the development of young individuals. Regular propagation by seeds and absence of turfness promote their accumulation in the coenopopulation $(23.52 \%)$, which is also expressed in high value of the index of recovery $(\mathrm{Ir}=0.36)$. Young growth develops not far from maternal individuals. Soil moisture, which is saved due to density of grasses also promotes accumulation of young individuals. The biological feature of D. charkeviczii, the individual particulation at the late mature generative stage and replenishment of coenopopulations with not rejuvenated particles defines low value of the index of senescence (Is=0.29). Age and efficiency estimation shows that coenopopulation 2 is at the transient stage (Table. 2).

Comparison of recovery and senescence indices among coenopopulations showed that the species regeneration

Table 1. The biometric characteristics of adult plants of Dracocephalum charkeviczii Probat.

\begin{tabular}{lll}
\hline Traits & \multicolumn{2}{l}{ Coenopopulation } \\
\cline { 2 - 3 } & No. 1 & No. 2 \\
\hline The length of leaf blade, cm & $3.7 \pm 0.17$ & $3.5 \pm 0.15$ \\
The width of leaf blade, cm & $0.4 \pm 0.01$ & $0.4 \pm 0.02$ \\
The length of inflorescence, cm & $6.4 \pm 0.18$ & $5.8 \pm 0.17$ \\
The number of whorls in inflorescence, pcs. & $4.1 \pm 0.17$ & $3.3 \pm 0.15$ \\
The number of vegetative shoots, pcs. & $3.4 \pm 0.06$ & $2 \pm 0.05$ \\
The number of generative shoots, pcs. & $10.5 \pm 0.33$ & $8.3 \pm 0.25$ \\
The height of generative shoot, cm & $35.6 \pm 1.29$ & $27.1 \pm 0.97$ \\
Height of vegetative shoot, cm & $27.3 \pm 1.04$ & $13.5 \pm 0.59$ \\
\hline
\end{tabular}

Table 2. Demographic characteristics of the coenopopulations of Dracocephalum charkeviczii Probat.

\begin{tabular}{|c|c|c|c|c|c|c|c|c|c|c|c|c|c|}
\hline \multirow[t]{2}{*}{ Coenopopulation } & \multicolumn{8}{|c|}{ Ontogenetic states: (\%) } & \multicolumn{5}{|c|}{ Demographic parameters } \\
\hline & $\mathrm{j}$ & $\mathrm{im}$ & $\mathbf{v}$ & g1 & g2 & g3 & ss & s & $\mathbf{P}$ & $\Delta$ & $\omega$ & Ir. & Ist. \\
\hline No. 1 & 2.24 & 2.24 & 3.37 & 6.73 & 20.23 & 44.94 & 15.75 & 4.49 & 10.5 & 0.63 & 0.70 & 0.09 & 0.67 \\
\hline No. 2 & 7.84 & 3.92 & 11.76 & 11.76 & 35.29 & 17.65 & 7.84 & 3.92 & 8.5 & 0.46 & 0.69 & 0.36 & 0.29 \\
\hline
\end{tabular}

Note: Ontogenetic states: $\mathrm{j}$ - juvenile, im - immature, $\mathrm{v}$ - virginal, g1 - young generative, g2 - mature generative, g3 - old generative, ss subsenile, $\mathrm{s}$ - senile; CP - coenopopulation; $\omega$ - index of efficiency; $\Delta$ - index of age; $\mathrm{P}-$ density, individuals $/ \mathrm{m}^{2}$; Ir - index of recovery; Is - index of senescence 
process in grass-dragonhead meadow (coenopopulation 1) passed slower than that in species-rich meadow (coenopopulation 2).

Values of density of $D$. charkeviczii individuals in all coenopopulations are rather high $\left(8.5-10.5\right.$ individ $\left./ \mathrm{m}^{2}\right)$ (Table 2), which is explained by different reasons. In coenopopulation 1 such an abundance is mainly linked with disintegration of individuals as a result of particulation and isolation of uneven-aged particles which provide a high density of the plants of this population $(g 3+\mathrm{ss}+\mathrm{s}=65.18 \%)$; in coenopopulation 2 a large proportion of individuals is of seed origin $(j+i m+v+g 1=70.57 \%)$ due to favorable conditions for seed germination and accumulation of young plants.

\section{CONCLUSIONS}

Dracocephalum charkeviczii Probat. has the short-rhizome monocentric life form. Ontogenesis pattern of seed individuals differs from that of vegetatively emerging particles. The individual development may be expressed through successively replacing each other morphogenesis phases: primary shoot $\rightarrow$ primaty bush $\rightarrow$ loose bush $\rightarrow$ tillering particle $\rightarrow$ not tillering particle. The results showed that ontogenesis of $D$. charkeviczii indivuduals is similar to that of closely related species from the subgenus Ruyschiana (D. argunense and D. ruyschiana). The differences are manifested in the shift on the monocarpic shoot of the renewal zone closer to the soil surface to the last metamer with scaly and metameres with transitional leaves, in the absence of branching of the first order enrichment shoots and the "main axis" phase in the morphogenesis of $D$. charkeviczii individuals. Studied D. charkeviczii coenopopulations are rather stable. The analysis of the coenopopulations revealed the availabilty of monomodal ontogenetic spectra with the maximum on middle-aged and old generative individuals. The ontogenetic structure of coenopopulations is governed by species biology and growth conditions (availability of free substrate, degree of turfness of the coenosis, moistening) which affect duration of the mature generative stage and replenishment of the coenopopulations of young individuals of seed origin.

All D. charkeviczii coenopopulations studied are normal, with rather high density. In coenopopulation 1 the individual density is determined by individual disintegration and formation of a great number of uneven-aged particles, in coenopopulation 2 - by appearance of a great number of individuals of seed origin.

\section{ACKNOWLEDGEMENTS}

The authors express their thanks to professor V.A. Cheryomushkina for valuable advises and to E.A. Chubar for the assistance in determination of species in plant communities. The work was carried out within the framework of the State Assignment of Central Siberian Botanical Garden, SB RAS № AAAA-A17-117012610053-9.

\section{LITERATURE CITED}

Antonova, I.S., K.S. Baikov, E.V. Baikova, O.A. Belova, Yu.A. Bobrov, A.G. Bystrushkin, O.E. Valuyskikh, O.N. Vishnitskaya, L.E. Gatsuk, I.A. Getmanets et al. 2008
Modern approaches to the description of structure of plants. LLC Loban, Kirov, 355 pp. (in Russian). [Антонова И.С., Байков К.С., Байкова Е.В., Бобров Ю.А., Быструшкин А.Г., Валуйских О.Е., Вишницкая О.Н., Гацук А.Е., Гетманец И.А. и Ар. 2008. Современные поАходы к описанию структуры растений. Киров: ООО Мобань. 355 с.].

Budantsev, A.L. 1993. The tribe Nepeta Benth of the family Lamiaceae Lindl. (taxonomy, geography, practical use). Diss. doct. sci. Saint-Petersburg, 455 pp. (in Russian). Буданцев А.А. 1993. Триб́a Nepeta Benth семейства Lamiaceae Lindl. (систематика, география, возможности использования). Аис. Аок. биол. наук. Санкт-Петербург. 455 с.].

Cheryomushkina, V.A. 2004. Biology of Allium of Eurasia. Nauka, Novosibirsk, 280 pp. (in Russian). ЧЧеремушкина В.А. 2004. Биология муков Евразии. Новосиб̆ирск: Наука. 280 с.]

Chistyakova, A.A. 2011. Ontogenesis and the state of populations of rare forest-steppe plants as a reflection of community ecology. In: Modern problems of population ecology, geobotany, systematics and floristics, vol. 1. (Yu.A. Dorogova et al., eds), pp. 236-242, Kostroma (in Russian). [Чистякова А.А. 2011. Онтогенез и состояние популяций редких растений ^есостепи как отражение экологии сообществ // Современные проблемы популяционной экологии, геоботаники, систематики и фмористики / отв. реА. Ю.А. Аорогина и Ар. Кострома. Т. 1. С. 236-242].

Denisova, G.R. \& Yu.M. Kovalyova 2007. Ontogenesis of Dracocephalum ruyschiana L. In: Ontogenetic atlas of plants, vol. 5 (L.A. Zhukova, ed.), pp.175-178. MarSU, Yoshkar-Ola (in Russian). [Аенисова Г.Р., Ковалева Ю.М. 2007. Онтогенез змееголовника Руйша (Dracocephalum ruyschiana L.) // Онтогенетический атлас растений / отв. реА. А.А. Жукова. Йошкар-Ола: МарГУ. Т.5. С.175-178].

Denisova, G.R., V.A. Cheryomushkina, A.Yu. Astashenkov \& E.B. Talovskaya 2018. The ontomorphogenesis and assessment of populations of the genus Dracocephalum argunense Fisch. et Link. on the border of the area. Botanicheskii Zhurnal 103(4):427-440 (in Russian with English summary). [Аенисова Г.Р., Черемушкина В.А., Асташенков А.Ю., Таловская Е.Б. 2018. Онтоморфогенез и оценка состояния ценопопуляций Dracocephalum argunense Fisch. et Link. на границе aреала // Ботанический журнал. Т. 103, №4. C. 427-440].

Gatsuk, L.E., O.V. Smirnova, L.I. Vorontzova, L.B. Zaugolnova \& L.A. Zhukova 1980. Age states of plants of various growth forms: a review. Journal of Ecology 68(2): 675-696.

Glotov, N.V. 1998. On the evaluation of the parameters of the age structure of the plant population. In: The life of populations in a beterogeneous environment, part 1 (L.A. Zhukova et al., eds), pp. 146-149. Periodicals of Mary El, Yoshkar-Ola (in Russian). [ГАотов Н.В. 1998. Об оценке параметров возрастной структуры популяций растений // Жизнь популяций в гетерогенной среАе / реА. А.А. Жукова и Ар. Йошкар-Ола: Периодика Марий Э^. Ч. 1. С. 146-149].

Harper, J.L. 1977. Population biology of plants. Academic Press, London, New York, 892 pp.

Kozhevnikov, A.E., Z.V. Kozhevnikova, M. Kvak \& B.Yu. Li 2015. Illustrated flora of southwest Primorye (Russian Far East). Korea, 409 pp. (in Russian). [Кожевников A.E., Кожевникова 3.В., Квак М., Аи Б.Ю. 2015. ИлАюстрированная флора юго-западного Приморья (Российский АаАьний Восток). Корея. 409 с.]. 
Odum, E.P. 1975. Ecology. Holt, Rinehart \& Winston, New York, Chicago, San Francisco, Atlanta, Dallas, Montreal, Toronto, London, Sydney, 244 pp.

Pimenova, E.A. (ed.) 2016. Plants, fungi and liches of the SikhoteAlin reserve. Dalnauka, Vladivostok, 557 pp. (in Russian). Растения, грибы и Аишайники Сихотэ-А^инского заповедника / отв. ред. Е.А. Пименова. ВАадивосток: Аальнаука. 557 с.]

Probatova, N.S. \& T.V. Krestovskaya 1995. Lamiaceae. In: Vascular plants of the Soviet Far East, vol. 7 (S.S. Charkevich, ed.), pp. 294-379, Nauka, Saint-Petersburg (in Russian). [Пробатова Н.С., Крестовская Т.В. 1995. Яснотковые - Lamiaceae / / Сосудистые растения советского Аальнего Востока / отв. реА. С.С. Харкевич. Санкт-Петербург: Наука. Т. 7. С. 294-379].

Rabotnov, T.A. 1950. The life cycle of perennial herbaceous plants in the meadow cenoses. Trudy Botanicheskogo Instituta im. V.L. Komarova Akademii Nauk SSSR. Geobotanika. 3(6): 179-196 (in Russian) [Работнов Т.А. 1950. Жизненный цикл многолетних травянистых растений в муговых ценозах // Труды БИН АН СССР. Геоботаника. Серия 3. Выпуск 6. С. 179-196].

Rabotnov, T.A. 1975. Study of cenotic populations in order to elucidate the "life strategies" of plant species. Byulleten" Moskovskogo Obschestva Ispytatelei Prirody, otdel Biologia 80(2):5-7 (in Russian). РРаботнов T.A. 1975. Изучение ценотических популяций в целях выяснения "стратегий жизни“" виАов растений // Бюлметень Московского общества испытателей природы. ОтАел биологический. Т. 80, № 2. С. 5-7].

Rockwood, L.L. 2006. Introduction to population ecology. Blackwelt Publ., London, 309 pp.

Savinykh, N.P. \& V.A. Cheryomushkina 2015. Biomorphology: Current status and prospects. Contemporary Problems of Ecology 8(5):541-549.

Serebryakov, I.G. 1962. Ecological morphology of plants. Vysshaya shkola, Moscow, 378 pp. (in Russian). [Серебряков И.Г. 1962. Экологическая морфология растений. Москва: Высшая школа. 378c.].

Serebryakova, T.I. 1971. Morphogenesis of shoots and evolution of life forms of grasses. Nauka, Moscow, 360 pp. (in Russian). [Серебрякова Т.И. 1971. Морфогенез побегов и эвомюция жизненных форм змаков. Москва: Наука. 360 c.].

Serebryakova, T.I. \& T.G. Sokolova (eds) 1988. Plant coenopopulations (essays of population biology). 1988. Nauka, Moscow, 182 pp. (in Russian). Ценопопуляции растений: (очерки популяционной биологии) / поА реА. Т.И. Серебряковой и Т.Г Соколовой. 1988. Москва: Наука. 182 с.].

Shishkin, B.K. 1954. Lamiaceae. In: Flora of URSS, vol. 20 (B.K. Shishkin \& S.V. Yuzepchuk, eds), pp. 471-473. Academiae scientiarum URSS, Moscow, Leningrad (in Russian). Б.К. Шишкин. 1954. Lamiaceae // ФАора СССР / отв. реА. Б.К. Шишкин, С.В. Юзепчук. М-А: ИзА-во Академии наук СССР. Т. 20. С. 471-473].
Smirnova, O.V. \& A.A. Uranov 1976. Coenopopulations of plants (Basic terms and structure). Nauka, Moscow, 215 pp. (in Russian). [Смирнова О.В., Уранов А.А. 1976. Ценопопуляции растений: (основные понятия и структура). Москва: Наука. 215 с.].

Smirnova, O.V. \& N.A. Toropova 2004. The main features of the population biology of plants (edificators and assectators) of the modern forest belt. General views of population biology and plant ecology In: Eastern European forests: history in the Holocene and modernity, vol. 1 (O.V. Smirnova, ed.), pp. 154-164. Nauka, Moscow (in Russian). [Смирнова О.В., Торопова Н.А. 2004. Основные черты популяционной биологии растений (эдификаторов и ассектаторов) современного месного пояса. Общие представления популяционной биологии и экологии растений // Восточноевропейские леса: история В голоцене и современность / отв. ред. О.В. Смирнова. Москва: Наука. Т. 1. C. $154-164]$.

Tabuldin, Yu.Z. 2009. Rare species of flora, limiting factors and issues of their protection in the territory of Perevolotsky district. Vestnik. Orenburgskogo gosudarstvennogo universiteta 6:365-366 (in Russian). ГТабульдин Ю.3. 2009. Редкие виды фморы, мимитирующие факторы и вопросы их охраны на территории Переволоцкого района // Вестник Оренбургского государственного университета. № 6. С. 365-366].

Uranov, A.A. 1975. Age spectrum of phytocoeno-population as a function of time and energy wave processes. Biologicheskie nauki 2: 7-34 (in Russian). [Уранов A.A. 1975. Возрастной спектр фитоценопопуляций как функция времени и энергетических волновых процессов / / Биологические науки. № 2. С. 7-34].

Warming, E. 1884. Über perenne gewachse. Botanischen Centralblatt 18(19):16-22.

Zhivotovskii, L.A. 2001. Ontogenetic states, effective density, and classification of plant populations. Russian Journal of Ecology 32: 1-5.

Zhukova, L.A. 1987. Dynamics of coenopopulations of meadow plants: Abstr. ... Diss. Doct. Sci.. Novosibirsk, 32 pp. (in Russian). [Жукова А.А. 1987. Аинамика ценопопуляций муговых растений. Автореф Аис. ... Аокт. биол. наук. Новосибирск. 32 с.].

Zhukova, L.A. 1995. Population life of meadow plants. Lanar, Yoshkar-Ola, 223 pp. (in Russian). [Жукова А.A. 1995. Популяционная жизнь муговых растений. ЙошкарО^а: Аанар. 223 с.].

Zlobin, Yu.A., V.G. Sklyar \& A.A. Klimenko 2013. Populations of rare plant species: theoretical foundations and methods of study. The University Book, Sumy, 439 pp. (in Russian). [3Аобин Ю.А., Скляр В.Г., КАименко А.А. 2013. Популяции реАких вилов растений: теоретические основы и методика изучения. Сумы: Университетская книга. 439 с.]. 